\title{
Public utility companies in liberalized markets - The impact of management models on local and regional sustainability
}

Santiago Mejia-Dugand, Olof Hjelm and Leenard Baas

The self-archived postprint version of this journal article is available at Linköping University Institutional Repository (DiVA):

http:/ / urn.kb.se/ resolve?urn=urn:nbn:se:liu:diva- 144151

N.B.: When citing this work, cite the original publication.

Mejia-Dugand, S., Hjelm, O., Baas, L., (2017), Public utility companies in liberalized markets - The impact of management models on local and regional sustainability, Utilities Policy, 49, 137-144.

https:// doi.org/ 10.1016/j.jup.2017.05.002

Original publication available at:

https:// doi.org/ 10.1016/j.jup.2017.05.002

Copyright: Elsevier

http:/ / www.elsevier.com/

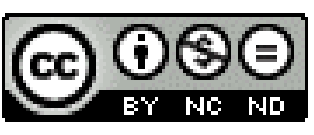


Public utility companies in liberalized markets

The impact of management models on local and regional sustainability

Santiago Mejía-Dugand*1, Olof Hjelm², Leo Baas²†

${ }^{1}$ School of Management, Universidad de los Andes. Calle 21 \#1-20, Bogotá, Colombia.

2Department of Management and Engineering, Environmental

Technology and Management, Linköping University, 58183 Linköping, Sweden.

\begin{abstract}
This article analyzes how publicly-owned utility companies can remain competitive in liberalized markets. We study EPM, a utility company from Medellín, Colombia. We discuss the company's management model, local laws and regulations affecting it, direct and indirect benefits for the city, and risks resulting from the power it has acquired. It is claimed that early decisions to maintain public ownership of key assets and provide the company with administrative autonomy helped it remain competitive, despite the liberalization of the market. This has allowed the city to increase its revenue and, as a result, its spending on social and environmental projects.
\end{abstract}

Keywords: Multi-utility companies, Liberalized utility markets, Economic autarky, Sustainability transitions, Public ownership, Mixed management models.

\title{
1. Introduction
}

Although many of the problems arising from urbanization and the use of technology have been widely acknowledged, the central role that cities and their regions play in the search for sustainability transitions was not seriously considered until 1987, with the Brundtland report (Bulkeley and Betsill, 2005). Urban sustainability, however, is a controversial concept. It is controversial because of the relativity that comes along with it, i.e. how closely tied any definition might be to the particular context being analyzed, and inevitably biased towards a

tProfessor Emeritus Leo Baas passed away in 2016. This article is dedicated to his memory. 
geographically-defined area (Hansson, 2010; Hult, 2013; McFarlane, 2006; Walker et al., 2015; Whiteman et al., 2011). In addition, the actors involved and the methods used to reach any sustainability goal play a particularly central role. What is seen today as the improvement of a city's sustainability performance was not necessarily the initial goal when projects or programs started to be thought about or implemented. Connecting the dots to develop models and understand the origin of improvements can thus become difficult under these conditions. Moreover, even under different conditions, the predictability power of models based on past behavior has received stark criticism (see e.g. Geels, 2011; Smith et al., 2005). Forecasting socio-technical behavior is a complicated enterprise.

Bulkeley and Betsill (2005) claimed that the role of cities in reaching global sustainability is not clear in practice. However, urban technologies represent an opportunity to decrease the impact they have on the environment (see also Vojnovic, 2014). The benefits to cities and their inhabitants resulting from the implementation of technology are obvious to many. In fact, as Gandy (2005) discusses, technology is one of the main characteristics of modern urban settlements, and an important explanation of their attractiveness as a social arrangement. More than the availability of technology, it is the intensity of its use that strengthens the cities' attractiveness: it is not a surprise that so-called "global cities" are characterized by their intense use of technology (see e.g. Hodson and Marvin, 2010; Nastar, 2014; Vojnovic, 2014). As we will later discuss, utilities and the infrastructure required to provide them play a particularly central role. However, an exclusively technocentered approach to sustainability can reduce the sustainability debate and the cities' role in it to discussions of an administrative nature (Bulkeley and Betsill, 2005; Hodson and Marvin, 2010; Mejía-Dugand, 2016; Neto, 2016). The role of local actors and their agency must be also considered in the models and frameworks directed at understanding sustainability transition processes (Gailing and Röhring, 2016; Mejía-Dugand, 2016; Smith et al., 2005).

McFarlane (2006) claims that categorizing cities according to their comparative level of development (i.e. economic, political or technological) might hinder the possibility of learning between and among contexts (see also Robinson (2011)). In this article, we analyze the case of Empresas Públicas de Medellín (hereon referred to as EPM), a utility company owned by the city of Medellín, Colombia, with the intention to provide an example outside the favored global circle, or what Hodson and Marvin (2009, 2010) call "ordinary cities," with a focus on its 
management model, and its approach to sustainability and infrastructure transitions. It is clear that the public nature of EPM motivates to a great extent its social behaviors. However, as we will discuss throughout the article, these are also propelled by what Shah and Arjoon (2015) define as the main intrinsic needs for self-determination: competence (i.e., feeling effective in its ongoing interactions with the social environment), autonomy (i.e., perceiving itself as the origin of its own behavior), and relatedness (i.e., feeling connected to stakeholders).

The aim of this article is to discuss EPM's management model, and the impacts it has had on local and regional environmental and social sustainability. To support this aim, the following questions will be addressed:

- What values and management model has EPM adopted to address social, environmental, and normative challenges?

- What type of national/local regulations have influenced the company's operation, and how do they affect/support the company's capacity to impact the city's and the region's sustainability?

This case promises to contribute to the discussion on entrepreneurial cities looking to increase their citizens' wellbeing through municipally-owned corporations that are commercial and social at the same time. It also contributes to the debate about operational efficiency between the private and the public sectors, and the central role that utility providers play in the construction of more sustainable cities and regions. Whiteman et al. (2011) say that cities provide a new context for research in business management and organization studies. Throughout the article, we will argue that technology has played and continues to play a central role in the well-being of citizens, the generation of revenues to promote and support development, and the transition into more sustainable cities and regions. Ultimately, this case study can contribute with good practices from emerging economies, which face particular challenges sparsely addressed in the literature.

\section{Cities and their Socio-Technical Configurations}

We have discussed in the introduction the central role that cities play in debates about global sustainability. Hodson and Marvin $(2009,2010)$ claim that some of the world's most powerful cities are undertaking initiatives to deliberately reconfigure their socio-technical regimes. It is not surprising that these cities attract attention due to the regional and global power 
they have, the influence they exert on other cities, their capacity to undertake large technological/infrastructural projects, and their spread use of urban technologies (Nastar, 2014; Taylor, 2005). However, these authors also recognize the importance of addressing transitions happening outside this group of cities (which McFarlane (2010) calls the "usual suspects"), and suggest including them as relevant cases for the study of sustainability transitions.

Mejía-Dugand et al. (2013:85) discuss the successful transition of the transport sector in South American cities as "a matter of nonhierarchical connections, where each element (city) is affected/influenced and at the same time each element affects/influences any other element." This claim supports the relevance of analyzing transitions that occur outside the favored circles of premium world cities. Even in a globalized world in which connections grow at an unprecedented pace, geographical, political, cultural and economic conditions might require a more flexible analysis, one that gives more importance to local conditions. These considerations are crucial, taking into account that dominant ideas of what a sustainable city is are to a great extent abstractions of values, norms and practices of dominant socio-technical models, i.e. North American, or Northern and Western European cities (Hult, 2013; McFarlane, 2010; MejíaDugand, 2016; Pierre, 2005). Strong local institutions can contribute as intermediaries to envision and coordinate transitions and influence the dominant regimes by protecting and embracing local values and common goals (Hodson and Marvin, 2009) .

Analyzing the acceptance or rejection of technology at the societal level is a complicated enterprise, considering the vast number of groups and their interpretation of what a given technology means or the benefits it represents. New concepts must overcome the obduracy of existing structures and the distrust that actors feel when new concepts are introduced (Baas, 2005; McLoughlin et al., 2000; Mejía-Dugand, 2016; Mejía-Dugand et al., 2013). External actors encounter therefore strong resistance and find it difficult to transmit the benefits that in their view they will entail, and their technology might be inappropriate since technological change is a "localized learning by doing process" (Fu et al., 2011:1209). Local actors, vernacular knowledge, and indigenous ingenuity thus play a fundamental role in facilitating this process (Mejía-Dugand, 2016; Memon et al., 2006).

Söderholm and Wihlborg (2015) highlight in their study the active role of the central state in transition processes in Sweden 
through the coordination of stakeholders, values, knowledge and instruments. Hodson and Marvin (2009, 2010) focus more on the role of what they call intermediaries, or actors that are in charge of creating collective understandings of the local context. They also build social networks of actors who work in favor of the achievement of the collective vision while highlighting their importance in long-term and complex changes (see also Van Lente et al. (2003)). These intermediaries can be, as Hodson and Marvin (2009) state, public or private, governmental or non-governmental.

In this direction, it is crucial to understand the underlying social structures behind any intended transition. From a "macro" perspective, the degree of institutional support, the economic significance of any given decision, and the political legitimacy it entails are important issues to consider (Smith and Stirling, 2008). From a "meso" perspective, the role of the public sphere, its proximity to technology, and its awareness of or engagement with change are central (Walker and Cass, 2007). At the "micro" level, innovation support, and the "shielding, nurturing and empowerment" properties of protective spaces are to be considered (Smith and Raven, 2012). Although sometimes influenced by external groups or trends, societies form in an independent manner an image of what a problem represents for them, how they will deal with it, and what their goal is regarding the solution's scope (Bohman and Raitio, 2014; Hillman et al., 2011). With this in mind, it is important to consider who is defining the problem, who wins and who loses with any suggested solution, whose problems they are, and from which perspective they are being analyzed (Bohman and Raitio (2014), and Smith and Stirling (2008) presented a similar argument).

\section{Methodology}

This article is mainly based on field work conducted in Medellín, Colombia, between 2013 and 2014. Two field trips took place to the city, during which the intention was to visit different development projects, perform interviews with representatives from agencies and institutions believed to play a central role in the city's socio-technical transformation during the last century, and perform archival work on the history of the city and some of its institutions. Seven interviews were conducted with actors belonging to municipal agencies in charge of advancing infrastructure projects in the city, agencies at the county's level in charge of planning and infrastructure projects, and the utility company. Interviewees were selected considering their involvement in current and past infrastructure projects (e.g. 
water, electricity and waste collection systems, public transportation projects, and an innovation district) and their knowledge about local relations among actors at the municipal, regional, and national levels.

Interviews followed a semi-structured methodology (Yin, 2009). Discussions were focused on the role of technology-mainly in the form of Large Technical systems-and on the transition the city has undergone during the last few decades (see e.g. Brand and Dávila, 2011; Cerdá et al., 2012; Furlong, 2014, 2015; Stienen, 2009). Since the significance of the utility company was detected at an early stage of the research process, special attention was put on its role, and on characteristics such as its management strategy and power position in Medellín's society. Seven additional recorded interviews were provided by a local university, in which local academicians and former employees of the utility company narrated and discussed historical facts of the company and its development.

As mentioned earlier and as will be discussed later in this article, the disadvantage of studying cities outside preferential circles is that they are normally underrepresented in mainstream journals and academic databases. This was addressed by using local libraries and other local reference centers to have access to documents and sources that were not available electronically, something that Yin (2009) recommends. Local and international magazines, and newspapers found through these sources contributed with useful information about the development of technical systems and the social and political processes affecting this development.

Walker et al. (2015) discuss that the amount of unpredictability of change causes uncertainty for key organizational members, and thus has an impact on environmental performance. EPM was selected as a case study due to the importance of the management of public services and the particularity of the environment in which EPM operates (i.e., Latin America). It is thus seen as a critical case useful to achieve logical deduction (Flyvbjerg, 2006). In addition, as Enticott and Walker (2008) claim, the private sector attracts most research on sustainability and performance. EPM's management model is interesting as it sheds light on the idea of urban entrepreneurialism, i.e. municipally-owned corporations that are commercial and social at the same time, and deliver what Fonseca (1999) calls "fourth generation" public services. 


\section{The Contribution of Utilities to Sustainable Cities and Regions}

The concept of "domestic and public utilities" (DPU) is normally defined without reference to the environment. The environment has gained more attention in publications about DPU, but there is no explicit reference to them as a product, e.g. "green" or "eco" DPUs (Montoya Brand, 2005). This is probably due to conceptual difficulties that emerge when trying to connect production and consumption in this sector, and the blurry divide between them (at least for users). Rather, what utility companies have focused on to address such intersection is the use of descriptors such as "renewable energy" or "sustainable energy systems."

Direct contributions from utility companies are not always easy to assess. In particular, the case of Medellín poses this challenge in the sense that many of the social, economic, and environmental improvements that have happened over time have been made possible, at least in part, thanks to the successful commercial strategy (and thus the generation of economic revenue for the city), and not exclusively to the provision of the actual services its utility company provides. The intention of this section, however, is to highlight both direct and indirect contributions from EPM and its operations to the performance of the city and the region in terms of sustainability.

Uncontrolled and unplanned urban sprawl is a commonly-mentioned problem that threatens the sustainability of urban settlements in the long run (see e.g. Guimarães et al., 2016). In particular, the inherent individualism of cities (where consumption occurs) as self-contained units (Furlong, 2014) has made the domination over the countryside (where production occurs) more evident. Water use (both direct and indirect), for instance, has greatly shifted from rural to urban, following urbanization trends (Neto, 2016).

This has not only caused alarming inequalities, but also economic migration into cities, which is the case of the region where Medellín is located, and its many small rural settlements. For example, before the regional energy system was integrated in 2007, rural inhabitants living close to the power plants would have to pay higher energy fees than those living in the city.1 Thus, entrepreneurs were forced to migrate in order to have access to better conditions and better run their businesses. After the integration, fees were leveled (i.e., rural fees decreased drastically while urban fees increased slightly) and

1 Guimarães et al. (2016) describe a similar situation for water and sanitation in Brazil. 
economic migration has halted to some extent. The unification has also brought benefits like the expansion of energy coverage, which has helped rural communities to decrease or eliminate their reliance on expensive and/or polluting and unhealthy energy carriers (e.g., batteries, coal, charcoal, kerosene, or dung). The conversion to cleaner energy carriers or more energyefficient home appliances has also been facilitated in the urban areas. Since the unification of the administration of all the utilities in one company (something uncommon, according to Memon et al. (2006), and highlighted by González-Gómez et al.(2014) as a good practice in the sector), invoicing has become more efficient and allowed the company to build a robust database of all the households in the city. With the intention to increase coverage, and thus consumption (i.e. with both a well-being and a commercial interest), EPM has financed the adoption or replacement of home appliances (e.g. gas stoves). The repayment of these appliances is made easy through the utilities invoice that comes every month. A similar approach has been used by EPM to promote the conversion of vehicles from petrol to natural gas, a successful case of cleaner technology implementation (MejíaDugand, 2010).

An additional benefit the city has had from EPM is the ambitious project for the recovery of the river that runs south to north at the bottom of the valley where the city is located. This river has been mistreated for decades now, directly receiving untreated discharges from the industrial and residential sectors. In 2000, EPM opened a wastewater treatment plant which serves $20 \%$ of the wastewater generated in the valley. A new plant is being built to treat the remaining wastewater in the near future. The cleaning of the river basin is an attempt by the city's administration to recover long-lost areas and return them to the city's inhabitants. An ambitious plan to build green areas and places where inhabitants can meet by the river has been taking shape during the last years. The uncontrolled and unplanned growth of the city, together with lax construction regulations, left citizens of Medellín without enough green spaces where they could interact among themselves and with nature, conditions considered as necessary for urban sustainability (Whiteman et al., 2011).

From another perspective, EPM created a foundation which represents an additional contribution to the redistribution of benefits for which the company stands. The objective of this foundation is to promote innovative, scientific and environmental activities. Varela Barrios (2010) highlights that this is uncommon in Colombia, where it is normally private companies that, looking for tax benefits, embrace such initiatives, i.e., their motivation is normally extrinsic (Shah and Arjoon, 2015). 
Finally, and conscious of the disparity between the city and the countryside, and the strong dependence on environmental services for the sustainability of the company and the city it serves, EPM has been greatly involved in $\mathrm{BanCO}_{2}$, a local initiative directed at the conservation of forests and water bodies in a kind of carbon footprint compensation scheme. As of September 2014, EPM had agreed to directly support 56 families which would protect between 56 and 168 hectares of land within the area of influence of the company's energy transmission and distribution businesses.

\section{The Birth of EPM}

In the beginning of the 20th century, the most important services fueling industrial and urban growth in the city were scattered and separated, managed by different specialized boards and private providers (López D, 2005). As the city and its industrial sector were expanding, the need to municipalize these services and label them as public became evident, especially since private entrepreneurs were not able to cope with the requirements of such expansion.

The vision of a modern city, projected nationally and internationally, required a reliable and modern provision of public services (Uribe and Valencia, 2005). Such vision was mainly influenced by the ruling elite: a beautiful city, equipped with excellent infrastructure and public services for all its citizens. Although -as Uribe and Valencia (2005) discuss- this vision was somehow elitist (considering that average citizens were only receptors of such a process and participation was limited), the public sphere and the coverage of public services expanded significantly (see also Luzi et al. (2008) for a discussion on elitist types of networks). This seems to be in line with what walker et al. (2015) found in their study, i.e., that although stakeholder consideration is important, temporal orientation (e.g., short vs. long term orientation) may be even more important for a better environmental performance. Similarly, Enticott and Walker (2008) advise in their study of English local authorities to focus attention on financial efficiency or service quality.

Such reality started to give shape to the establishment of a single entity that would administer utilities centrally, since the individual companies depended almost entirely on political decisions, did not have a legal status, were subject to budget control and surveillance, and constantly risked being used as parafiscal resources by the municipality's administration (Uribe and Valencia, 2005). The ruling elite realized that it was 
necessary to adopt a system that allowed it to continue pursuing social interests by keeping public ownership, while at the same time benefitting from the provision of public services and the fulfillment of growing demands (Ospina, 1966).

According to Furlong (2014), Medellín has historically spent more on public services (on a per capita basis) than any other municipality of the region it belongs to, and more recently, more than the other four largest cities in the country. The World Bank opposed the integration of the separate entities administering the different public services, but the city had acquired enough experience and reputation to stand strong for its decisions. The Bank, however, urged the public company's disassociation from all kinds of political issues, which had to wait some years, until the law contemplated such a possibility (López D, 2005).

In 1955, the central government authorized the city's administration to "organize one or several of the municipal services of the City of Medellín, separately or jointly, as entities with administrative autonomy" (The Colombian Government, 1955, Article 1). More importantly, these entities should be of an "apolitical nature, ruled by a rigorous administrative efficacy criterion, for which the adequate technical systems for corporate organization must be used" (The Colombian Government, 1955, Article 2, 12a).

EPM was created in 1955, when the Administrative Council of the city of Medellín decreed the emergence of "an autonomous establishment in charge of the direction, administration and provision of the municipal public services of electricity, telephony, drinking water, and sewage" (The Administrative Council of Medellín, 1955, Article 1). The primordial goal of such an establishment was to "guarantee the citizens the regular, permanent and economical functioning of the required public services and to promote at the same time the progress of Medellín by supporting the emergence of new industries and the growth of the ones already established" (The Administrative council of Medellín, 1955, Article 23). Notable evidence of the long-term vision of the ruling elite at that time is the authorization to provide its services to municipalities outside the city's administrative boundaries, only "if by doing so, the fulfillment of the needs of the city of Medellín and its citizens or companies is not jeopardized; these have to be prioritized" (The Administrative Council of Medellín, 1955, Article 26). Such an authorization would prove useful more than five decades later, when EPM started its ambitious expansion strategy, something we will discuss later. 
In summary, three early decisions were fundamental to the future performance of EPM: its apolitical nature, its administrative autonomy, and the authorization to provide its services outside the city's boundaries. These issues will be discussed in the following section, with an emphasis on autonomy.

\section{Autonomy and a Mixed Management Model: Keys to Success?}

The emergence of the "autonomous entity" mentioned above was justifiable by the existence of a natural monopoly, ${ }^{2}$ and the need to comply with the requirements set by multilateral funding agencies for the expansion of infrastructure (Botero García and López Álvarez, 2005). Such a concept worked well for EPM which, according to Vélez Álvarez (2013), was able to operate without major interference from professional politicians. However, the strong influence that the private sector had on its administration clashed with the growing power that the political class was gaining, which managed to tip the balance towards political meddling. This resulted in a period of instability at the top management level (Vélez Álvarez, 2013). Since then, the general manager has been appointed by the mayor (who at that time was appointed by the county's governor, who was in turn appointed by the president). Competition, as previously mentioned, was not really a concern that EPM had to struggle with, but politicking certainly was (Botero García and López Álvarez, 2005).

EPM had managed to demonstrate good performance and high administrative skills, something that allowed the technocracy to keep the autonomy of the company through time, a victory of the technical realm over the political one (López D, 2005). Although the situation in Medellín and other major cities in Colombia was stable (e.g. Cali and Bogotá), and citizens had access to goodquality public services, this was not necessarily the case in the rest of the country. According to Fiszbein (1997), the poor quality of services resulted in popular uprising in the 1970 s and 1980s. The prevailing model during the last decades had been that of a paternalistic state, which resulted in inefficiency that could be attributed to the strong centralization of power and administrative tasks, the lack of funding, excessive corruption and political favors ${ }^{3}$ (Bernal Pulido, 2005). This is something

2 See Felgendreher and Lehmann (2016), González-Gómez et al. (2014), and Thomas (2000) for discussions on different interests for utility providers in Peru, Spain, and the United Kingdom, respectively.

${ }^{3}$ See Memon et al. (2006) for a similar discussion, and González-Gómez et al. (2014) for a discussion on the disadvantages of fragmentation and the dispersion of responsibility. 
that would start to change in 1986, when the democratic election of mayors was implemented, and power and resources were transferred to local, democratically-elected authorities. According to López D (2005), EPM gained a special place in the history of decentralization in Colombia, by establishing its leadership in the sector and basing its entrepreneurial focus on its administrative autonomy.

\subsection{The Liberalization of the Utilities Market}

Political reforms and more resources prompted the emergence of an environment in which local governments could be more effective (Fiszbein, 1997). However, neoliberal and pro-privatization ideologies were gaining popularity in the region, and the relationship between private ownership and efficiency was taken for granted.4 The idea that public companies did not have the proper incentives to optimize and decrease costs, and were dangerously susceptible to political pressures, was permeating the political class (Páez Pérez and Silva Ruiz, 2010). To a great extent, these ideas facilitated the emergence of Law 142 in 1994, which created a level field for all providers to compete in the public services market.

Under this new framework, state-owned companies had the option to become joint-stock companies, or exceptionally, what would be called State Industrial and commercial companies, which was a concept strongly lobbied for by politicians from the county where Medellín is located. Such a framework would allow the city to retain public ownership of the company, but govern it following the private, rather than the public law. In 1997, EPM became a State Industrial and Commercial Company administered at the municipal level, a decentralized public establishment of an apolitical nature, and endowed with autonomy for the administration of public services. EPM managed to maintain administrative stability and independence from political influence (Fiszbein, 1997). Its management model integrates strategic centralization with operational autonomy, operationalized through different business units. However, a corporate center coordinates all the efforts, similar to a multicorporate holding (Varela Barrios, 2010).

The long-lasting struggle for autonomy has paid off, but has required resources, administrative tools, and a technical approach to management (López D, 2005). The professionalization of the staff has been an indispensable tool to support autonomy, and EPM is perhaps, according to Varela Barrios (2010), the

4 See Memon et al. (2006), who discuss this trend in Asia, and Bohman and Raitio (2014), who present the case of Africa. 
company that has invested the most in training, advisory and consultancy services in Colombia. Such a strategy has allowed the generation of knowledge, expertise and intellectual capital, and the possibility to leave outsourced operators to handle the activities that add the least value (Varela Barrios, 2010).

The decision to transform EPM into a state Industrial and Commercial Company after the emergence of Law 142 has had a dramatic impact on its political and social importance (Furlong, 2014). In addition, the company itself has undergone an internal change, from a local public services provider to a strictly commercial company with national and international outreach (Vélez Álvarez, 2013). This has of course brought significant benefits to the city, the company's sole owner: while in 1997 the city received roughly USD 21 million, that figure grew to USD 446 million in 2010 (Vélez Álvarez, 2013). In turn, these transfers' participation in the city's budget has also grown: the average for the period 2007-2011 was 27\%, reaching 32\% in 2008 (Vélez Álvarez, 2013). These transfers have represented different percentages of the company's profits. By local statutes, "ordinary transfers" must not exceed 30\%. However, "extraordinary transfers" are allowed, after negotiating them with the city's government and after approval from the city council. Furlong (2014) reports that since extraordinary transfers were formalized in 2007, the city's spending on social projects increased by $129 \%$. This "30\% rule" has guaranteed a constant flow of income to the municipality without harming the company's ability to pursue its own expansion plans.

Allowed by law to provide its services outside the city's administrative boundaries, EPM has embarked on an ambitious national and international expansion strategy. The company has relied on the growth of its coverage for the fulfillment of its role of generating resources for its owners. After 1995, a significant expansion process began, mainly within Colombia. Although EPM continues to rely greatly on the local market (Furlong, 2015), national market share is limited by law, which caps the company's expansion. This condition motivated the decision to expand the company outside national borders. Although some investments had been made in Panama in 2003, 2010 was the year when EPM's international expansion really took off. Since then, the company has invested in the energy, water treatment/distribution and telecommunications markets in Panama, Guatemala, El Salvador, Chile, USA, Spain and Mexico. The company set the goal to reach $40 \%$ of its commercial activities abroad by 2015 (Furlong, 2014). 


\section{Protecting Socio-Technical Regimes from Shocks}

Current debates on sustainability and governance focus on how to influence transitions into a desired path (see e.g. Grin et al., 2010). This path is not necessarily an emerging opportunity, but is defined by the pursuit of a collective goal (Geels, 2011). How a certain society decides to address certain events happening on the macro level depends on that society's collective goals, i.e. the common understanding of what the problem is, and of the mechanisms and networks that must be built in order to address it (Hillman et al., 2011).

In the case of Medellín, the common goal was not explicitly one in which sustainability played a central role, at least not in the terms in which it is understood in more modern times. The common vision defined by the city focused on expanding the coverage of the utilities and maintaining or improving their quality in order to guarantee the well-being of the city's inhabitants and support the growth of its industrial sector. This meant that the surrounding regions, central to the provision of electricity and drinking water also needed to be addressed, not only in terms of social justice, but also in order to fight economic migration into the well-served city (see Neto, 2016). In view of this, a former CEO of EPM said in an interview:

"The central government allocated a budget that would allow the regional government to expand its electricity coverage by one thousand households every year. There were eighty thousand households unserved, so it would have taken eighty years to do so. Why wait? Today, the coverage in the region is $96 \%-97 \%$."

It is commonly accepted that public services and utilities are central to transitions into sustainability. Network-bounded infrastructure systems such as electricity, gas, water, telecommunications, waste, and transport have been considered by different authors as important components for the advancement of sustainability transitions (see e.g. Konrad et al., 2008; Lieberherr and Truffer, 2015; Luzi et al., 2008; Mejía-Dugand et al., 2013; Raven, 2007).

In this article, we are interested in highlighting events from the macro level that can exert pressure on socio-technical regimes and create instability. Although instability can be seen as a window of opportunity to advance change (Geels, 2002), this is not always the case, as we will discuss by describing the case of Medellín. In particular, the city's administration and EPM have had to protect regimes from the following shocks: 
The attempt to politicize the utility company

As the city's political class was gaining power, the different and separate companies in charge of the provision of utilities were subject to constant budget control, and faced the risk of being used as parafiscal resources, which would leave them with little freedom to ensure their financial viability (Uribe and Valencia, 2005). The industrial elite supported and promoted the creation of a single company that would not only administer the provision of all the utilities centrally, but would also be of an apolitical nature and endowed with administrative autonomy. This would allow the company to pursue its mandate without major intervention from politicians. The opportunity to endow the company with administrative autonomy was made in order to safeguard the public interest and guarantee the provision of the utilities, but also to ensure a reliable source of revenue that would allow the city to pursue other common goals. This is important for the deployment of long-term plans that seek to achieve a social vision (Hodson and Marvin, 2010).

As the company gained power, the risk of politicization also grew. Given that the company's CEO is appointed by the mayor, it is no surprise that since the popular election of mayors was established in 1986, every new mayor has replaced the CE0 when they have come into office. Even so, the company has managed to keep its stability thanks to the low rotation of second and third-tier executives and its long-term financial planning (Vélez Álvarez, 2013). In addition, public control of the company -which has become a central civic authority and is respected and protected by the citizens- has allowed it to survive further attempts to undermine its autonomy: Furlong (2014) says that it has been society, not government regulators, whom have been central actors during these crises, which can be considered a sign of what Shah and Arjoon (2015) label as relatedness. In fact, a former CEO of EPM explained:

"The company has built a strong reputation in the city and sense of belonging among the citizens. Society has built ad hoc control systems to defend the company from politicization. When the company is at risk: ALARM!! A committee is created and is dissolved when the crisis is overcome." 
The liberalization of the utilities market

Hodson and Marvin (2009) highlight the importance of understanding how cities shape their infrastructures, especially if they have little control over private and often liberalized systems. Seeing privatization as a threat or as an opportunity depends largely on the political views of society, and on the objectives it has set to better serve the public interest (see e.g. Amran and Haniffa, 2011; Memon et al., 2006). As it was described above, the liberalization of the utilities market in Colombia occurred in 1994. This decision followed the growing support of privatization initiatives in the continent.

EPM had built a strong reputation due to its operational efficiency and the coverage level of the utilities it administered. With the emergence of the liberalization law, the administration saw the need to protect its utilities company, realizing the advantages that a natural monopoly had created and the knowledge the company had accumulated so far. The city of Cali followed a similar path, although it failed to shield its company from the influence of the political class, and has struggled for years to save it from bankruptcy (Vélez Álvarez, 2010).

The liberalization of the market can be seen as a shock from two perspectives. First, EPM was a stable and reliable source of revenue for the city. Second, the establishment of fees through market mechanisms could destabilize the equilibrium achieved through the design of a cross-subsidies scheme, in which wealthy citizens pay higher fees in order to help finance the poor's. 5 The subdirector of the county's planning unit explained why this poses a threat to the city, by focusing on waste collection:

"In a city so segregated as Medellín, a private waste management company would go to well-off neighborhoods and offer their services. They could offer them to collect their waste every day, and would probably get everyone as customers. They would also offer a lower fee. The city loses 'estrato 6' [i.e. the highest socio-economic stratum], which was subsidizing the poorest citizens. EPM still has to collect waste in 'estrato 1 ' [i.e. the lowest socio-economic stratum]."

Losing the subsidies is not in the interest of the poor, for obvious reasons. In addition, Uribe and Valencia (2005) imply that this is not in the interest of the wealthy either, since

5 Guimarães et al. (2016, p. 2) highlight the need for "[t]ools for good governance [...] to cover marginal situations." 
they promote a model of a modern, clean, healthy, competitive and sustainable city, and want to diffuse it to the rest of society, especially to poor immigrants that come to the city and settle in the periphery.

The particular conditions under which EPM operates, i.e. its economic autarky and its market-oriented management, make it sometimes difficult to discern between what is private and what is public (Varela Barrios, 2010). However, it can be said that EPM acts as a strategic intermediary that supports sociotechnical transitions in the city, since among other things, it is network-based (i.e., it facilitates and coordinates the exchange of information among multiple actors at the sociotechnical regime level), and has a focus on a broad technological sector (Hodson and Marvin, 2009). EPM provides institutional capacity through lobbying for legal rules and contributing to the achievement of common goals with knowledge and expertise, something that Söderholm and Wihlborg (2015) highlight as crucial in their study of sociotechnical transitions in swedish municipalities, and Shah and Arjoon (2015) label competence. Stakeholders accept the company's advice and direction, supported by the high degree of technical expertise and the knowledge of the technological systems that comprise the city, acquired after sixty years of administering them.

In a city, socio-technological interventions require resources, consensus and leadership (cognitive and normative governance mechanisms; see Hillman et al. (2011)), and the shaping of relationships between technology and the local context (Hodson and Marvin, 2009; Whiteman et al., 2011). Opportunities to innovate are motivated by collective goals and the coordination of the actors involved. Socio-technical stability and utility coverage expansion have guaranteed the constant generation of resources necessary to undertake large-scale socio-technical transitions. Also, and central to this article, although publicly-owned companies are seen by some as lacking in innovativeness in comparison to private companies, they can actually motivate and support the emergence of innovations directed at urban sustainability when they are governed by mixed practices (Lieberherr and Truffer, 2015).

\section{Discussion and Conclusions}

The concept of DPUs does not consider sustainability as a central criterion, but rather the fulfillment of human needs (Montoya Brand, 2005). This poses an enormous challenge for companies that face the conundrum of environmental degradation (e.g. from 
hydropower dams) versus its mandate to provide public services to a constantly-growing population. Modern technical systems create significant barriers for the internalization of externalities by utility users. In addition, a strong reliance on technology for sustainability brings about the risk of creating a society in which technocratic knowledge replaces legal or ethical considerations: a technocratic government can become inaccessible in terms of political decisions (Montoya Brand, 2005).

EPM has an undoubtedly great lobbying capacity and civic authority. This has been and is useful for the design of convenient public policies that could be beneficial for its operation and, as a result, for its owner (i.e. the city of Medellín). However, the great power that the company has acquired could represent a barrier to other technologies or service providers (not necessarily in conflict with the core interests of EPM). One of the interviewees, when discussing alternative local waste collection systems, expressed his discontent with the fact that "EPM thinks it owns the city," when in fact it is merely another market player-it just happens to be the largest and strongest. Autonomy, economic autarky and the liberalization conditions under which EPM operates create a blurry line between what is private and what is public (Varela Barrios, 2010).

Utility companies use different strategies to achieve a similar final state (Walker et al., 2015). In this study, public ownership showed to be an important variable for the Colombian case. This fact is strongly influenced by the context under which public services have evolved in the country and the region. However, public ownership alone does not provide a good explanation of EPM's performance in terms of service provision and financial health. Such conclusion cannot be reached without considering the fact that the company received administrative autonomy and is allowed to follow regular commercial market strategies while preserving its public ownership. In particular, autonomy has allowed the company to make its own strategic decisions without adhering to political flags and whims, and clear and solid statutes have shielded the company's financial viability by establishing the amounts it is allowed to transfer to the municipality, the ladder of priorities, and the conditions for doing so. At the same time, popular involvement has proven to be an indispensable tool for the protection of this condition, as well as for the surveillance of the fulfillment of the company's mandate to pursue the well-being of the inhabitants of the city of Medellín -a social contract between the company and its inhabitants. 


\section{Acknowledgments}

The authors want to thank the Swedish Governmental Agency for Innovation Systems (VINNOVA) and the Metabolism of Megacities project at the University of Toronto for their financial support. The authors also want to thank Federico Restrepo, Juan Diego Lopera, María Elena Mora, and Juan Carlos Restrepo, who kindly agreed to be interviewed on short notice. A big thank you goes also to Marcela Pizano Castillo, Luis Fernando Mejía Robles, and Beatriz Elena Arias, whose help in contacting interviewees and finding relevant information was fundamental for the development of this study. Comments from two anonymous reviewers are greatly appreciated.

\section{References}

Amran, A. and Haniffa, R. (2011). Evidence in Development of Sustainability Reporting: A Case of a Developing Country. Business Strategy and the Environment 20, 141-156.

Baas, L.W. (2005). Cleaner Production and Industrial Ecology Dynamic Aspects of the Introduction and Dissemination of New Concepts in Industrial Practice. Delft: Eburon Academic Publishers.

Bernal Pulido, C. (2005). El Concepto de Servicio Público Domiciliario en el Ordenamiento Jurídico Colombiano [The Concept of Household Public Services in the Colombian Legal System]. Letras Jurídicas 10(1), 105-142.

Bohman, A. and Raitio, K. (2014). How Frames Matter - Common Sense and Institutional Choice in Ghana's Urban water sector. Journal of Environment and Development 23(2), 247-270.

Botero García, J.A. and López Álvarez, G.A. (2005). Economía, Política Económica y Servicios Públicos: Medio Siglo de las Empresas Públicas de Medellín [Economy, Economic Policy and Public Services: Half a Century with Empresas Públicas de Medellín]. Letras Jurídicas 10(1), 77-104.

Brand, P. and Dávila, J.D. (2011). Mobility Innovation at the Urban Margins - Medellín's Metrocables. City: Analysis of Urban Trends, Culture, Theory, Policy, Action 15(6), 647-661.

Bulkeley, H. and Betsill, M. (2005). Rethinking Sustainable Cities: Multilevel Governance and the 'Urban' Politics of Climate Change. Environmental Politics 14(1), 42-63. 
Cerdá, M., Morenoff, J.D., Hansen, B.B., Tessari Hicks, K.J., Duque, L.F., Restrepo, A., Diez-Roux, A.V. (2012). Reducing Violence by Transforming Neighborhoods: A Natural Experiment in Medellín, Colombia. American Journal of Epidemiology $175(10), 1045-1053$.

Enticott, G. and Walker, R.M. (2008). Sustainability, Performance and Organizational Strategy: An Empirical Analysis of Public Organizations. Business Strategy and the Environment 17, 79 92 .

Felgendreher, S. and Lehmann, P. (2016). Public Choice and Urban Water Tariffs - Analytical Framework and Evidence from Peru. Journal of Environment and Development 25(1), 73-99.

Fiszbein, A. (1997). The Emergence of Local Capacity: Lessons from Colombia. World Development 25(7), 1029-1043.

Flyvbjerg, B. (2006). Five Misunderstandings about Case-Study Research. Qualitative Inquiry 12(2), 219-245.

Fonseca Z, C. (1999). Hacia los Servicios Públicos de "Cuarta Generación": Las Empresas de Capital Social [Towards "Fourth Generation" Public Services: Social Capital Companies]. Contexto 6, 58-75.

Fu, X., Pietrobelli, C., and Soete, L. (2011). The Role of Foreign Technology and Indigenous Innovation in the Emerging Economies: Technological Change and Catching-Up. World Development 39(7), 1204-1212.

Furlong, K. (2014). Growing the Multi-Utility: The Rise and Expansion of the Empresas Públicas de Medellín (EPM). Paper presented at the International Roundtable Conference; 10-13 June; Tutzing, Germany.

Furlong, K. (2015). Water and the Entrepreneurial City: The Territorial Expansion of Public Utility Companies from Colombia and the Netherlands. Geoforum 58, 195-207.

Gailing, L. and Röhring, A. (2016). Is it all about collaborative governance? Alternative ways of understanding the success of energy regions. Utilities Policy 41, 237-245.

Gandy, M. (2005). Cyborg Urbanization: Complexity and Monstrosity in the Contemporary City. International Journal of Urban and Regional Research 29(1), 26-49. 
Geels, F.W. (2002). Technological Transitions as Evolutionary Reconfiguration Processes: A Multi-Level Perspective and a Case-Study. Research Policy 31, 1257-1274.

Geels, F.W. (2011). The Multi-Level Perspective on Sustainability Transitions: Responses to Seven Criticisms. Environmental Innovation and Societal Transitions 1, 24-40.

González-Gómez, F., García-Rubio, M.A., and González-Martínez, J. (2014). Beyond the public-private controversy in urban water management in Spain. Utilities Policy 31, 1-9.

Grin, J., Rotmans, J., and Schot, J. (2010). From Persistent Problems to System Innovations and Transitions. In: Transitions to Sustainable Development: New Directions in the Study of Long Term Transformative Change, Grin. J., Rotmans, J., and Schot, J. (eds). New York: Routledge.

Guimarães, E.F., Malheiros, T.F., and Marques, R.C. (2016). Inclusive governance: New concept of water supply and sanitation services in social vulnerability areas. Utilities Policy 43, Part A: 124-129.

Hansson, S.0. (2010). Technology and the Notion of Sustainability. Technology in Society 32, 274-279.

Hillman, K., Nilsson, M., Rickne, A., and Magnusson, T. (2011). Fostering Sustainable Technologies: A Framework for Analysing the Governance of Innovation Systems. Science and Public policy 38(5), 403-415.

Hodson, M. and Marvin, S. (2009). Cities Mediating Technological Transitions: Understanding Visions, Intermediation and Consequences. Technology Analysis and Strategic Management $21(4), 515-534$.

Hodson, M. and Marvin, S. (2010). Can Cities Shape SocioTechnical Transitions and how would we know if they were? Research Policy 39, 477-485.

Hult, A. (2013). Swedish Production of Sustainable Urban Imaginaries in China. Journal of Urban Technology 20(1), 7794 .

Konrad, K., Truffer, B., and Voß. J-P. (2008). Multi-Regime Dynamics in the Analysis of Sectoral Transformation Potentials: Evidence from German Utility Sectors. Journal of Cleaner Production 16, 1190-1202. 
Lieberherr, E. and Truffer, B. (2015). The Impact of Privatization on Sustainability Transitions: A Comparative Analysis of Dynamic Capabilities in Three water Utilities. Environmental Innovation and Societal Transitions 15, 101-122.

López D, J.C. (2005). La Génesis de Empresas Públicas de Medellín: El Camino a la Autonomía [The Genesis of Empresas Públicas de Medellín: The Road to Autonomy]. Letras Jurídicas 10(1), 9-30.

Luzi, S., Hamouda, M.A., Sigrist, F., and Tauchnitz, E. (2008). Water Policy Networks in Egypt and Ethiopia. The Journal of Environment and Development 7(3), 238-268.

McFarlane, C. (2006). Crossing Borders: Development, Learning and the North-South Divide. Third World Quarterly 27(8), 14131437 .

McFarlane, C. (2010). The Comparative City: Knowledge, Learning, Urbanism. International Journal of Urban and Regional Research $34(4), 725-742$.

McLoughlin, I., Badham, R., and Couchman, P. (2000). Rethinking Political Process in Technological Change: Socio-Technical Configurations and Frames. Technology Analysis and Strategic Management 12(1), 17-37.

Mejía-Dugand, S. (2010). Evaluation of the Availability of Raw Materials for Biogas Production in Medellín, Colombia. Master's Thesis, Division of Environmental Technology and Management, Linköping University.

Mejía-Dugand, S. (2016). The Evolution of Sweden's Urban Sustainability Marketing Tool: A Comparative Study of Two Major International Events. Journal of Urban Technology 23(2), $65-80$.

Mejía-Dugand, S., Hjelm, 0., Baas, L., and Ríos, R.A. (2013). Lessons from the Spread of Bus Rapid Transit in Latin America. Journal of Cleaner Production 50, 82-90.

Memon, M.A., Imura, H., and Shirakawa, H. (2006). Reforms for Managing Urban Environmental Infrastructure and Services in Asia. The Journal of Environment and Development 15(2), 138157.

Montoya Brand, M. (2005). Servicios Públicos Domiciliarios y Pensamiento Ambiental: Una Aproximación [Household Public Utilities and Environmental Thinking: An Approximation]. Letras Jurídicas 10(1), 143-186. 
Nastar, M. (2014). The Quest to Become a World City: Implications for Access to Water. Cities 41, 1-9.

Neto, S. (2016). Water governance in an urban age. Utilities Policy 43, Part A: 32-41.

Ospina, E.L. (1966). Una Vida, una Lucha, una Victoria: Monografía Histórica de las Empresas y Servicios Públicos de Medellín [A Life, a Struggle, a Victory: Historic Monography of the Public Companies and Services in Medellín]. Medellín: Empresas Públicas de Medellín.

Páez Pérez, P.N and Silva Ruiz, J. (2010). Las Teorías de la Regulación y la Privatización de los Servicios Públicos [The Theories of Regulation and Privatization of Public Services]. Administración and Desarrollo 38(52), 39-56.

Pierre, J. (2005). Comparative Urban Governance. Uncovering Complex Causalities. Urban Affairs Review 40(4), 446-462.

Raven, R. (2007). Co-Evolution of Waste and Electricity Regimes: Multi-Regime Dynamics in the Netherlands (1969-2003). Energy Policy 35, 2197-2208.

Robinson, J. (2011). Cities in a World of Cities: The Comparative Gesture. International Journal of Urban and Regional Research $35(1), 1-23$.

Shah, K.U. and Arjoon, S. (2015). Through Thick and Thin? How Self-Determination Drives the Corporate sustainability Initiatives of Multinational Subsidiaries. Business Strategy and the Environment 24, 565-582.

Smith, A. and Raven, R. (2012). What is a Protective space? Reconsidering Niches in Transitions to Sustainability. Research Policy 41, 1025-1036.

Smith, A. and Stirling, A. (2008). Social-Ecological Resilience and Socio-Technical Transitions: Critical Issues for Sustainability Governance. STEPS Working Paper 8. Brighton: STEPS Centre.

Smith, A., Stirling, A., and Berkhout F. (2005). The Governance of Sustainable Socio-Technical Transitions. Research Policy 34, 1491-1510.

Söderholm, K. and Wihlborg, E. (2015). Policy for Socio-Technical Transition: Implications from Swedish Historical Case Studies. Journal of Environmental Policy and Planning 17(4), 452-474. 
Stienen, A. (2009). Urban Technology, Conflict Education, and Disputed Space. Journal of Urban Technology 16(2-3), 109-142.

Taylor, P.J. (2005). Leading world cities: Empirical Evaluations of Urban Nodes in Multiple Networks. Urban Studies 42(9), $1593-1608$.

The Administrative Council of Medellín. (1955). Acuerdo No. 58 de 1955 (6 de Agosto), Por Medio del Cual se organiza el Establecimiento Público Autónomo encargado de la Administración de los Servicios Públicos de Energía Eléctrica, Acueducto, Alcantarillado y Teléfonos [Agreement $n r .58$ (August $6^{\text {th }}$ ), by which the Public Autonomous Establishment in charge of the Administration of the Public Services of Electricity, Drinking Water, Sewage and Telephony is organized].

The Colombian Government. (1955). Decreto 1816 (Julio 01), Por el Cual se dan Autorizaciones al Municipio de Medellín [Order nr. 1816 (July $1^{\text {st }}$ ), by which the Municipality of Medellín is given authorization].

Thomas, D. (2000). Hyder: the rise and fall of a multi-utility. Utilities Policy 9, 181-192.

Uribe, M.T. and Valencia, G. (2005). Tensiones y Dilemas en la Prestación de los Servicios Públicos Domiciliarios en Colombia: Entre lo Público, lo Privado y lo Estatal [Tensions and Dilemmas in the Provision of Household Public Services in Colombia: Among the Public, the Private and the State's]. Letras Jurídicas 10(1), 31-76.

Van Lente, H., Hekkert, M., Smits, R., and van waveren, B. (2003). Roles of Systemic Intermediaries in Transition Processes. International Journal of Innovation Management $7(3), 247-279$.

Varela Barrios, E. (2010). Estrategias de Expansión y Modos de Gestión en Empresas Públicas de Medellín [Expansion Strategies and Management Methods in Empresas Públicas de Medellín, EPM]. Estudios Políticos 36, 141-165.

Vélez Álvarez, L.G. (2013). Evolución de las Empresas de Agua y Saneamiento de Medellín y Cali en Colombia: ¿Vidas Paralelas? [Evolution of the Drinking water and Sanitation Companies in Medellín and Cali, Colombia: Parallel Lives?]. Inter-American Development Bank, Nota Técnica \#IDB-TN-517.

Vojnovic, I. (2014). Urban Sustainability: Research, Politics, Policy and Practice. Cities 41, S30-S44. 
Walker, G. and Cass, N. (2007). Carbon Reduction, 'the Public' and Renewable Energy: Engaging with Socio-Technical Configurations. Area 39(4), 458-469.

Walker, K., Ni, N., and Dyck, B. (2015). Recipes for Successful Sustainability: Empirical Organizational Configurations for Strong Corporate Environmental Performance. Business Strategy and the Environment 24, 40-57.

Whiteman, G., de Vos, D.R., Chapin III, F.S., Yli-Pelkonen, V., Niemelä, J., and Forbes, B.C. (2011). Business Strategies and the Transition to Low-Carbon Cities. Business Strategy and the Environment 20, 251-265.

Yin, R.K. (2009). Case Study Research - Design and Methods, fourth ed. Thousand Oaks: Sage Publications. 